\title{
Clinical utility of tolvaptan in the management of hyponatremia in heart failure patients
}

This article was published in the following Dove Press journal: International Journal of Nephrology and Renovascular Disease 8 May 2010

Number of times this article has been viewed

\section{Savina Nodari ${ }^{1}$ \\ Geoffrey T Jao ${ }^{2}$ \\ Jun R Chiong ${ }^{3}$}

'Division of Cardiology, University of Brescia, Brescia, Italy; ${ }^{2}$ Section of General Internal Medicine, Wake Forest University Baptist Medical Center, Winston-Salem, NC, USA; ${ }^{3}$ Division of Cardiology, Loma Linda University, California, USA
Correspondence: Jun R Chiong Associate Professor of Medicine, Pharmacology and Outcomes Science, Director, Advanced Heart Failure Program, Loma Linda University, I 1234 Anderson Street, Suite 4404, Loma Linda, CA 92354, USA

Tel +I 909 558-9730 (office);

+l 909 809-0289 (mobile)

Email jchiong@llu.edu
Abstract: Hyponatremia is an electrolyte disorder frequently observed in several clinical settings and common in hospitalized patients with decompensated heart failure (HF). It is caused by deregulation of arginine vasopressin (AVP) homeostasis associated with water retention in hypervolemic or in euvolemic states. While hypervolemic hypotonic hyponatremia is also seen in advanced liver cirrhosis, renal failure, and nephrotic syndrome, the bulk of evidence associating this electrolyte disorder to increasing morbidity and mortality can be found in the HF literature. Hospitalized HF patients with low serum sodium concentration have lower short-term and long-term survival, longer hospital stay and increased readmission rates. Conventional therapeutic approaches, ie, restriction of fluid intake, saline and diuretics, can be effective, but often the results are unpredictable. Recent clinical trials have demonstrated the effectiveness of nonpeptide AVP receptor antagonists (vaptans) in the treatment of hyponatremia. The vaptans induce aquaresis, an electrolyte-sparing excretion of free water resulting in the correction of serum sodium concentrations and plasma osmolality, without activation of the renin-angiotensin-aldosterone system (RAAS) or changes in renal function and blood pressure. Further prospective studies in a selected congestive HF population with hyponatremia, using clinical-status titrated dose of tolvaptan, are needed to determine whether serum sodium normalization will be translated into a better long-term prognosis. This review will focus on recent clinical trials with tolvaptan, an oral $\mathrm{V}_{2}$ receptor antagonist, in HF patients. The ability of tolvaptan to safely increase serum sodium concentration without activating the RAAS or compromising renal function and electrolyte balance makes it an attractive agent for treating hyponatremic HF patients.

Keywords: hyponatremia, heart failure, AVP receptor antagonists, tolvaptan, serum sodium

\section{Introduction}

Sodium homeostasis is vital to the normal physiologic function of the cells. Sodium concentration is regulated by stimulation of thirst, secretion of antidiuretic hormone $(\mathrm{ADH})$, feedback mechanisms of the renin-angiotensin-aldosterone system (RAAS), and variations in renal handling of filtered sodium.

Hyponatremia is defined as serum sodium level of $<135 \mathrm{mEq} / \mathrm{L}$ and is considered severe when the serum sodium level is $<125 \mathrm{mEq} / \mathrm{L}$. It is an important and common electrolyte abnormality that can be seen in isolation or, as most often is the case, as a complication of other medical illnesses associated with hypervolemia such as heart failure (HF), liver cirrhosis and the syndrome of inappropriate antidiuretic hormone secretion (SIADH). ${ }^{1}$ 
The clinical manifestations depend on the severity and duration of hyponatremia and rapidity of decrease in sodium levels. Signs and symptoms of acute $(<48$ hours) severe hyponatremia are primarily related to the central nervous system as the osmotic pressure gradient promotes water movement into brain cells, resulting in life-threatening cerebral edema and encephalopathy. ${ }^{2}$ Patients with chronic hyponatremia or a serum sodium level from 125 to $134 \mathrm{mmol} / \mathrm{L}$ may be asymptomatic or have less severe symptoms (fatigue, nausea, vomiting, and anorexia).

However in spite of a less serious clinical manifestations, hyponatremia is a predictor of poor outcomes in patients with HF, and the pathogenesis of this disorder reflects the underlying severity of HF, as well as attempts to manage fluid overload. ${ }^{3}$ This review will focus on hyponatremia in HF setting and the role of the $V_{2}$ receptor antagonist tolvaptan in its management.

\section{Hyponatremia in heart failure Pathogenesis}

Hyponatremia is a common electrolyte disorder in patients with decompensated HF (19 to $25 \%)^{4,5}$ and is frequently a complication of diuretic therapy. ${ }^{6}$ Its pathogenesis is multifactorial. Neurohormonal activation, in response to decreased cardiac output, plays an important role in the pathophysiology of $\mathrm{HF}$ and hyponatremia. One of the most important etiologies of hyponatremia in this setting is an inappropriate secretion of AVP, making vasopressin receptors antagonism as a target for therapy for HF patients. ${ }^{7}$ The decrease of effective circulating volume and consequently the sympathetic nervous system (SNS) and RAAS activation lead to an increase in nonosmotically released AVP. The non-osmotic release of AVP might override the hypo-osmolality negative feedback on AVP production. ${ }^{8}$

Diuretic therapy induces hyponatremia because of the impairment of the kidney's capability to reabsorb solute in the absence of water, the reduction of glomerular filtration rate due to volume depletion and the activation of the AVP system due to effective circulating volume decrease. Furthermore, the activation of the RAAS and SNS in response to diuretics contributes to the development of electrolyte disturbances and blunts the kidney response to diuretics in an effort to compensate for the changes in sodium and water balance. ${ }^{8}$

Vasopressin through stimulation of $\mathrm{V}_{1}$ and $\mathrm{V}_{2}$ receptors aggravates the progression of HF, adversely affecting ventricular remodeling, worsening clinical congestion and contributing to hyponatremia. The $\mathrm{V}_{1 \mathrm{a}}$ receptor is a $\mathrm{G}$ protein-coupled receptor which, when activated, increases intracellular calcium through the inositol-triphosphate pathway. ${ }^{9}$ Prolonged $\mathrm{V}_{1 \mathrm{a}}$ receptor stimulation causes both arterial and venous constriction increasing myocardial preload and afterload. Direct myocardial $\mathrm{V}_{\mathrm{la}}$ receptor stimulation also contributes to left ventricular hypertrophy and adverse remodeling.

The $\mathrm{V}_{2}$ receptor, located in the renal collecting tubular cells, is linked to the adenylate cyclase signaling pathway, with intracellular cyclic adenosine monophosphate (cAMP) acting as the second messenger. $\mathrm{V}_{2}$ receptor mediates the $\mathrm{ADH}$-induced stimulation of water permeability thereby permitting osmotic equilibration with the renal interstitium. ${ }^{10}$ The inappropriate activation of the renal $\mathrm{V}_{2}$ receptors contributes to excessive water retention, volume expansion, increase of cardiac preload and dilutional hypo-osmolality with hypotonic hyponatremia. All these mechanisms perpetuate a vicious circle that can lead to disease progression and a worsening of the clinical status and prognosis of HF patients. ${ }^{11}$

\section{Prognostic significance}

Low serum sodium concentration in the setting of congestion may be a marker of increased neurohormonal activation and greater severity of disease. The prognostic importance of hyponatremia in patients with severe chronic HF was first described by Lee and Packer. ${ }^{12}$ Five variables including serum sodium concentration, left ventricular stroke work index, serum creatinine concentration, serum bilirubin, and age were found to predict survival and pretreatment hyponatremia was the most powerful predictor of long term prognosis.

Several later studies demonstrated that hyponatremia at the time of admission is related to poor outcomes in patients hospitalized for acute heart failure syndrome (AHFS). A randomized trial on 282 patients on the effect of nurse-directed, multidisciplinary intervention in comparison with usual care on 90-day readmission rates after AHFS hospitalization found that a decreasing plasma sodium level was one of the five independent predictors of readmission. ${ }^{13}$ Another study of 4031 community-based patients hospitalized for worsening HF has shown that hyponatremia is one of the multivariable predictors of mortality at both 30 days and 1 year. ${ }^{1}$

Similar results emerged from retrospective analyses of several large randomized clinical trials. Investigators explored the relationship between admission serum sodium concentration and short term mortality in the OPTIME-CHF trial. ${ }^{14}$ There were 949 patients with AHFS randomized to receive 48 to 72 hours of intravenous milrinone or placebo in addition to standard therapy. In this study population, 
$27 \%$ of patients were in the lowest sodium quartile (ie, serum sodium concentration $<135 \mathrm{mEq} / \mathrm{L}$ ). The number of hospitalization days for cardiovascular causes was 33\% higher in this group and they also had a 2-fold higher in-hospital and 60-day mortality compared to those in the other plasma sodium quartiles. Similar results were also noted in another study among HF patients with preserved systolic function and hyponatremia. ${ }^{15}$

An analysis from the OPTIMIZE-HF registry of 48,612 patients with AHFS showed a relationship between admission serum sodium concentration and clinical outcomes. ${ }^{16}$ Hyponatremia was present in $20 \%$ of the OPTIMIZEHF cohorts with similar prevalence in patients with reduced or preserved ejection fraction. Lower admission serum sodium levels were associated with higher in-hospital mortality and longer mean hospital length of stay. In the follow up cohort, admission hyponatremia was associated with higher 60- to 90-day mortality. Admission serum sodium concentration remained a significant independent predictor of outcomes after adjustment for other prognostic factors (Figure 1).

A post-hoc analysis of the ESCAPE trial evaluated the correlation of hyponatremia with hemodynamic status in patients hospitalized with severe HF. ${ }^{17}$ This study was designed to evaluate the utility of pulmonary artery catheter in 433 patients hospitalized with severe HF (NYHA IV and LVEF $<30 \%$ ). Patients were followed up for 180 days after discharge. Hyponatremia was initially present in $23.8 \%$ of study population and persisted during hospitalization in $68.9 \%$ of these patients. After covariate adjustment, results confirmed that baseline serum sodium levels were an independent predictor of 6 month mortality. Persistent hyponatremia was also associated with a significant increase of HF readmission rate as well as a composite endpoint of death and readmission rate. Moreover, the higher event rate associated with hyponatremic patients persists even after symptomatic and clinical improvement.

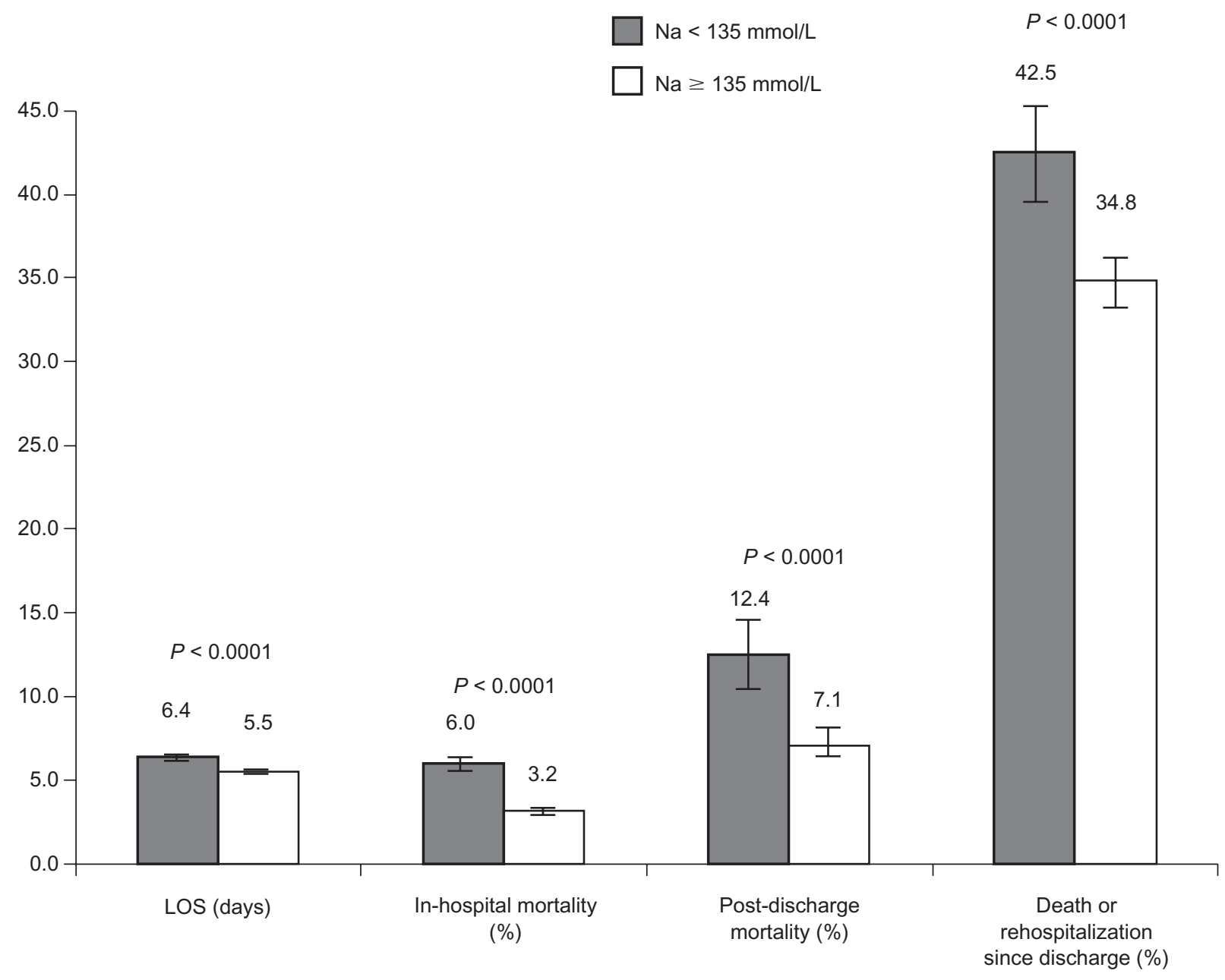

Figure I Hyponatremia and prognosis in heart failure patients. Abbreviation: LOS, length of stay. 
AVP $V_{2}$-receptor selective antagonist: tolvaptan

Mechanism of action, pharmacokinetic and pharmacodynamic profile

Tolvaptan, also known as OPC-41061, is an orally active nonpeptide AVP antagonist. It selectively blocks the binding of AVP to $\mathrm{V}_{2}$ receptor and inhibits the AVP-induced production of cyclic AMP in human cells expressing $V_{2}$ receptors. $\mathrm{V}_{2}$ receptor antagonism promotes free water clearance (aquaresis), decrease in urine osmolality, and rise of serum sodium concentration without disturbing plasma potassium and magnesium levels. Tolvaptan metabolites have none or minimal activity for human $\mathrm{V}_{2}$ receptors compared with active drug. ${ }^{18}$

The pharmacokinetic, pharmacodynamic and drug interactions between tolvaptan and furosemide or hydrochlorothiazide (HCTZ) were studied in 12 healthy white men. ${ }^{19}$ In subjects receiving $60 \mathrm{mg}$ of tolvaptan, the onset of the aquaretic and sodium increasing effects occurs within 2 to 4 hours post-dose. A peak effect is observed between 4 and 8 hours post-dose. Tolvaptan resulted in a greater 24-hour urine volume/excretion rate than furosemide or HCTZ. However, concomitant administration of tolvaptan with furosemide or HCTZ resulted in a similar 24-hour urine volume/excretion rate compared with tolvaptan administration alone. In clinical studies on CHF patients, the addiction of tolvaptan to standard therapy, included furosemide, induced an increase in urine output compared to placebo plus diuretic. To confirm this possible synergic effect in HF patients, studies comparing tolvaptan alone versus tolvaptan plus diuretic effects are necessary.

Tolvaptan is metabolized by CYP3A system and concomitant use of strong CYP3A inhibitors such as clarithromycin or ketoconazole is cautioned. ${ }^{20}$ Tolvaptan administration does not affect steady-state amiodarone concentration, an antiarrhythmic drug commonly prescribed for patients with congestive heart failure and a known inhibitor of other drugs metabolized by CYP3A4. Potent CYP3A inducers such as rifampicin reduced tolvaptan plasma concentrations by $85 \%$. Tolvaptan is also a substrate for P-glycoprotein and administration with P-glycoprotein inhibitors such as cyclosporine requires a dose reduction. ${ }^{21}$

Treatment with tolvaptan is associated with a reduction of the extracellular fluid volume which could result in increased serum potassium. Serum potassium levels should be monitored after initiation of tolvaptan treatment in patients with a serum potassium $>5 \mathrm{mEq} / \mathrm{L}$ and in those who are receiving drugs known to increase serum potassium levels. Although specific interaction studies were not performed in CHF clinical studies tolvaptan was used concomitantly with standard therapy (including beta-blockers, angiotensin receptor blockers, angiotensin converting enzyme inhibitors and potassium sparing diuretics) and plasma potassium concentrations are not significantly changed.

\section{Tolvaptan in experimental studies, human studies and clinical trials}

Preclinical studies, conducted on animals and in healthy subjects, showed that $\mathrm{V}_{2}$ receptor antagonist administration produced aquaretic effect (increase in free water excretion) without sodium loss, without activation of the RAAS and changes of renal function. ${ }^{22,23}$ These favorable results appeared to be consistent among several clinical trials on HF patients (Table 1).

Gheorghiade et al was the first to conduct a doubleblind, randomized trial to evaluate the ability of tolvaptan to remove excess fluid when added to a diuretic therapy in patients with symptomatic chronic HF. ${ }^{24}$ In this study, 254 outpatients with NYHA 2 or 3 HF were randomly assigned to receive placebo or one of three doses of tolvaptan $(30,45$, or $60 \mathrm{mg} /$ day) for 25 days in addition to standard therapy. The tolvaptan group demonstrated a significant decrease in body weight at day 1 that was maintained throughout the 25 days. Moreover, there was a significant improvement of clinical signs and symptoms observed. There was also an increase in urine output with significantly lower urine osmolality and urinary sodium concentration compared to placebo group. More hyponatremic patients in the tolvaptan group ( $80 \%$ vs $40 \%$ in placebo) had normalization in serum sodium levels. The increase in serum sodium starts at day 1 and maintained throughout the study. There were no changes in renal function or blood pressure.

The Acute and Chronic Therapeutic Impact of Vasopressin antagonist in congestive HF (ACTIV in CHF prospective trial) evaluated the clinical effects of tolvaptan in 319 patients hospitalized with worsening heart failure. All doses (30, 60, $90 \mathrm{mg}$ /day) of tolvaptan resulted in significant body weight reduction over placebo..$^{25}$ Tolvaptan also improved serum sodium levels in patients with hyponatremia. There were no differences in worsening heart failure at 60 days between the tolvaptan and placebo groups $(P=0.88)$. However, while bodyweight declined on tolvaptan, there were no statistically significant differences in the signs and symptoms of clinical congestion, except for dyspnea $(P=0.04)$. Of note, patients randomized to tolvaptan used less furosemide and maintained 
Table I Tolvaptan clinical trials in heart failure

\begin{tabular}{|c|c|c|c|c|c|}
\hline Study & $\begin{array}{l}\text { No. of patients and } \\
\text { characteristics }\end{array}$ & Dosage & Primary endpoint & Results and comments & $\begin{array}{l}\text { Adverse } \\
\text { effects }\end{array}$ \\
\hline $\begin{array}{l}\text { Gheorghiade } \\
\text { et } \mathrm{a}^{24}\end{array}$ & $\begin{array}{l}\mathrm{N}=254 \\
\text { Pts with CHF in } \\
\text { outpatient setting } \\
\text { (NYHA class I-IV) } \\
\text { and volume overload }\end{array}$ & $\begin{array}{l}\text { Tolvaptan } \\
\text { ( } 30,45 \text { or } \\
60 \mathrm{mg} / \text { day) for } \\
25 \text { days vs placebo }\end{array}$ & Decrease in body weight & $\begin{array}{l}\text { Significant decrease in body weight } \\
\text { in all tolvaptan groups at } 24 \mathrm{~h} \text {, with } \\
\text { a concomitant increase in urine } \\
\text { volume, lower urine osmolality and } \\
\text { urinary sodium concentration }\end{array}$ & $\begin{array}{l}\text { Dry mouth, } \\
\text { thirst and } \\
\text { polyuria }\end{array}$ \\
\hline $\begin{array}{l}\text { ACTIV in } \\
\text { CHF }^{25}\end{array}$ & $\begin{array}{l}\mathrm{N}=319 \\
\text { Pts with } \mathrm{EF} \leq 40 \% \\
\text { hospitalized for } \\
\text { congestive } \mathrm{HF}\end{array}$ & $\begin{array}{l}\text { Tolvaptan } \\
(30,60 \text { or } \\
90 \mathrm{mg} / \text { day) for } \\
\text { up to } 60 \text { days vs } \\
\text { placebo }\end{array}$ & $\begin{array}{l}\text { I) In hospital end-point: change } \\
\text { in body weight at } 24 \text { hrs } \\
\text { 2) Outpatient end-point: } \\
\text { worsening heart failure at } \\
60 \text { days after randomization }\end{array}$ & $\begin{array}{l}\text { Dose independent decrease } \\
\text { in body weight at } 24 \mathrm{~h} \text { in tolvaptan } \\
\text { group } \\
\text { No differences in worsening HF } \\
\text { at } 60 \text { days }\end{array}$ & $\begin{array}{l}\text { Thirst and dry } \\
\text { mouth, dizzi- } \\
\text { ness, nausea, } \\
\text { hypotension }\end{array}$ \\
\hline $\begin{array}{l}\text { SALT-I and } \\
\text { SALT-2 }{ }^{28}\end{array}$ & $\begin{array}{l}\mathrm{NI}=205 \mathrm{~N} 2=243 \\
\mathrm{CHF} \text { and other } \\
\text { hospitalized pts } \\
\text { with euvolemic or } \\
\text { hypervolemic } \\
\text { hyponatremia }\end{array}$ & $\begin{array}{l}\text { Tolvaptan } \\
\text { (15-60 mg/day) } \\
\text { for } 30 \text { days vs } \\
\text { placebo }\end{array}$ & $\begin{array}{l}\text { Change in serum sodium concen- } \\
\text { trations (from baseline to } 4 \text { th and } \\
\text { to } 30 \text { th day) }\end{array}$ & $\begin{array}{l}\text { Serum sodium concentrations } \\
\text { Increased significantly more with } \\
\text { tolvaptan during the first } 4 \text { days } \\
(P<0.00 \text { I }) \text { and after the full } \\
30 \text { days of therapy }(P<0.00 \text { I })\end{array}$ & $\begin{array}{l}\text { Thirst and dry } \\
\text { mouth, urinary } \\
\text { frequency }\end{array}$ \\
\hline Udelson ${ }^{29}$ & $\begin{array}{l}\mathrm{N}=240 \\
\text { Pts with HF } \\
\text { (NYHA class II/III) } \\
\text { and } \mathrm{EF} \leq 30 \%\end{array}$ & $\begin{array}{l}\text { Tolvaptan } \\
\text { ( } 30 \mathrm{mg} / \text { day) for } \\
\text { I year vs placebo }\end{array}$ & $\begin{array}{l}\text { To evaluate the effect of long-term } \\
\text { administration of tolvaptan on left } \\
\text { ventricular remodeling }\end{array}$ & $\begin{array}{l}\text { There was no difference on LV } \\
\text { volumes } \\
\text { *post hoc analysis: improvement } \\
\text { survival in tolvaptan group }\end{array}$ & $\begin{array}{l}\text { Urinary fre- } \\
\text { quency, thirst } \\
\text { and dry mouth }\end{array}$ \\
\hline $\begin{array}{l}\text { EVEREST } \\
\text { Clinical } \\
\text { Status Trial }^{31}\end{array}$ & $\begin{array}{l}\mathrm{N}=4 \mathrm{I} 33 \\
\text { Pts with } \mathrm{EF} \leq 40 \% \text {, } \\
\text { NYHA class III/IV, } \\
\text { hospitalized for } \\
\text { worsening CHF }\end{array}$ & $\begin{array}{l}\text { Tolvaptan } \\
\text { ( } 30 \mathrm{mg} / \text { day) for a } \\
\text { minimum of } \\
60 \text { days vs placebo }\end{array}$ & $\begin{array}{l}\text { I) Change in global clinical status } \\
\text { 2) Change in body weight at } \\
7 \text { days or at discharge }\end{array}$ & $\begin{array}{l}\text { Oral tolvaptan in addition to } \\
\text { standard therapy improved many, } \\
\text { though not all, heart failure signs } \\
\text { and symptoms, without serious } \\
\text { adverse events }\end{array}$ & $\begin{array}{l}\text { Thirst and dry } \\
\text { mouth }\end{array}$ \\
\hline $\begin{array}{l}\text { EVEREST Out- } \\
\text { come Trial }^{32}\end{array}$ & $\begin{array}{l}\mathrm{N}=4 \mathrm{I} 33 \\
\text { Pts with } \mathrm{EF} \leq 40 \% \text {, } \\
\text { NYHA class III/IV, } \\
\text { hospitalized for } \\
\text { worsening CHF }\end{array}$ & $\begin{array}{l}\text { Tolvaptan } \\
\text { ( } 30 \mathrm{mg} / \text { day) for } \\
\text { a minimum of } \\
60 \text { days vs placebo }\end{array}$ & $\begin{array}{l}\text { 1) All-cause mortality } \\
\text { 2) Composite of cardiovascular } \\
\text { death or hospitalization } \\
\text { for HF }\end{array}$ & $\begin{array}{l}\text { No effect (either favorable } \\
\text { or unfavorable) of long term } \\
\text { tolvaptan treatment }\end{array}$ & $\begin{array}{l}\text { Thirst and dry } \\
\text { mouth }\end{array}$ \\
\hline
\end{tabular}

Abbreviations: $\mathrm{CHF}$, chronic heart failure; $\mathrm{EF}$, ejection fraction; $\mathrm{HF}$, heart failure; $\mathrm{LV}$, left ventricular; NHYA, New York Heart Association.

a lower body weight, without differences in heart rate, blood pressure, potassium level or renal function. Retrospective analyses showed that patients with hyponatremia $(21.3 \%)$ had a threefold increase in 60-day mortality compared with normonatremic patients and the improvement in hyponatremia during hospitalization, even if modest, was associated with improved outcomes. ${ }^{26}$ Particularly a lower 60-day mortality in all tolvaptan groups compared to placebo group $(P<0.05)$ among patients with severe congestion and elevated blood urea nitrogen levels at baseline was detected. ${ }^{27}$

The Study of Ascending Levels of Tolvaptan in hyponatremia 1 and 2 (SALT-1 and SALT-2) evaluated the effect of tolvaptan in patients with either euvolemic or hypervolemic hyponatremia due to SIADH, chronic HF or cirrhosis. ${ }^{28}$ Tolvaptan was started at $15 \mathrm{mg} /$ day, increased to $30 \mathrm{mg} /$ day and then to $60 \mathrm{mg} / \mathrm{day}$, if necessary, based on serum sodium concentration. Tolvaptan was more effective than placebo in increasing the average daily area under the curve for serum sodium concentrations during the first 4 days and after the full 30 days of therapy. Within 8 hours of the first administration of tolvaptan (first observation point), the serum sodium concentration was significantly higher in the tolvaptan group for both the total population and the subgroups stratified according to the degree of hyponatremia.

A multicenter, double-blind, placebo-controlled study, demonstrated that long term (1 year) administration of the tolvaptan (30 mg/day), have no significant effect on reducing left ventricular end-diastolic and end-systolic volume in 120 patients with stable CHF (NYHA II/III). ${ }^{29}$ In this study there were no significant differences in serum sodium or potassium between groups across the year of therapy. A post hoc analysis showed a significant reduction in mortality and worsening HF over 1 year in patients treated with tolvaptan in comparison with placebo group $(P=0.027)$. 
These outcome findings were hypothesis generating of EVEREST program.

The EVEREST trial is a program of pivotal trials designed to investigate the effect of tolvaptan administration ( $30 \mathrm{mg}$ /day) in addition to standard therapy in 4133 patients hospitalized for AHFS with signs and symptoms of volume overload. EVEREST consisted of three studies: 2 identical studies (A and B) designed to investigate short-term effects on clinical status and symptoms and an outcome study consisting of all randomized patients designed primarily to investigate long-term clinical outcomes of all cause mortality and combined cardiovascular mortality or HF readmissions. ${ }^{30}$ The median follow-up period was 9.9 months. The short-term trials demonstrated a significant improvement in primary composite clinical end point (patient-assessed global clinical features and body weight loss at 7 day or discharge if earlier), and in secondary clinical end points (bodyweight loss at day 1 and day 7, patient-assessed dyspnea at day1, edema score at day 7) in patients treated with tolvaptan. ${ }^{31}$

Among patients with baseline serum sodium levels $<134 \mathrm{mEq} / \mathrm{L}$ ( $8 \%$ of total), the mean serum sodium concentration significantly increased in the tolvaptan group compared to placebo group. This effect was observed since day 1 and persisted throughout the follow-up period (Figure 2). In spite of the significant improvement in short-term clinical status outcomes and in increasing sodium serum concentration among hyponatremic patients, tolvaptan administration in addition to standard therapy did not affect long term mortality or heart failure-related morbidity. ${ }^{32}$ However dose titration of treatment considering clinical status (entity of dyspnea, peripheral edema, pulmonary congestion, body weight) and a dose adjustment based on clinical response could lead to better results in term of symptoms and outcomes.

Further prospective studies in a selected congestive HF population with hyponatremia, using clinical-status titrated dose of tolvaptan, are needed to determine whether serum sodium normalization will be translated into a better long-term prognosis.

\section{Safety and tolerability}

Symptomatic hyponatremia are true emergencies that demand prompt and definitive intervention. An important consideration in the treatment of hyponatremia is the rate at which serum sodium is corrected. Overly rapid correction of chronic hyponatremia leads to pontine and extrapontine myelinolysis that causes irreversible neurologic deficits. The challenge in treating severe hyponatremia is finding the right balance so as not to risk progression to cerebral edema from undercorrection of hyponatremia and avoid the osmotic demyelination syndrome from overcorrection of this electrolyte disorder.

Among patients with acute hyponatremia, defined as development of hyponatremia within 48 hours, the risk of persistent marked hyponatremia far exceeds any risk from correction of serum sodium and should not deter aggressive treatment. Patients seem to tolerate rates of correction that would be harmful for chronic hyponatremia ( $>48$ hours). ${ }^{33}$ There have been no reports of osmotic demyelination syndrome or related neurologic sequelae to date among patients who took or who are currently taking tolvaptan.

The data from clinical studies on short and long-term outcomes confirmed an overall safety profile of tolvaptan in a
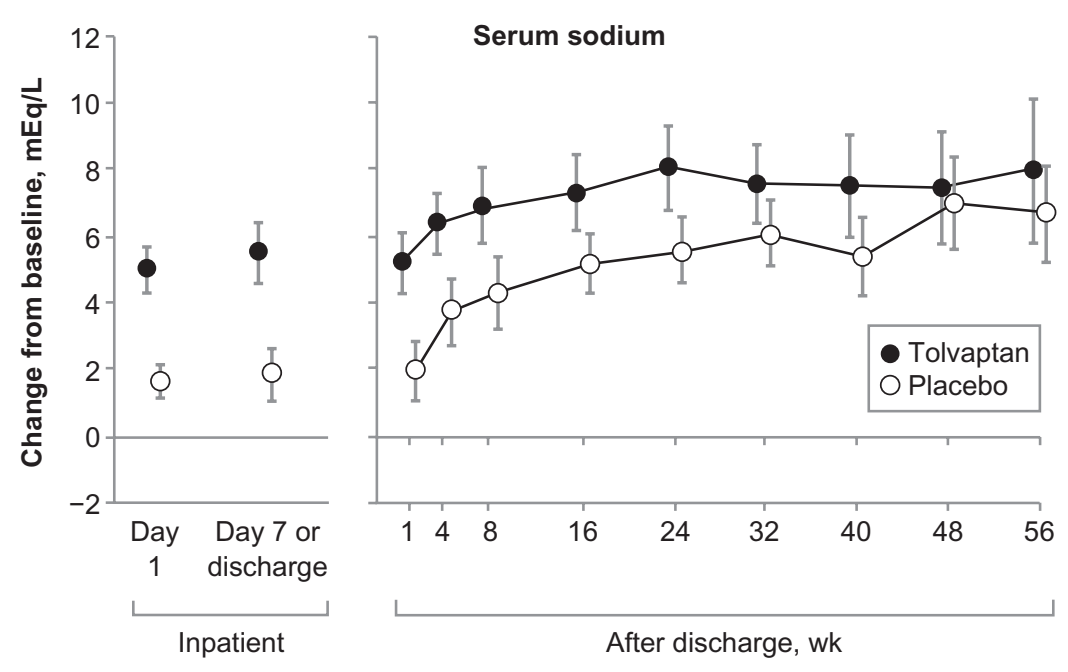

Figure 2 Changes in serum sodium level (EVEREST trial). 
very large population of patients with HF and hyponatremia. In the EVEREST program the benefits on short term outcomes (consistent increases in urine output, a reduction in body weight, and an improvement in many signs and symptoms) have been seen without unfavorable changes in blood pressure, heart rate, electrolytes, or renal function. The neutral long-term outcome effects, different from other treatments in AHFS, confirm the safety of tolvaptan chronically administered.

The most common adverse effects (incidence $\geq 5 \%$ than placebo) to tolvaptan reported in clinical trials were thirst, dry mouth, polyuria and urinary frequency, which are consistent with the pharmacologic action of the drug. Other side effects reported, but not statistically significant in comparison with placebo (standard therapy), includes dehydration with hypotension, acute renal failure and hyperglycemia. Tolvaptan should not be used in hypovolemic hyponatremia or in patients with glomerular filtration rate less than $10 \mathrm{~mL} / \mathrm{min} / 1.73 \mathrm{~m}^{2}$, such as those with end stage renal disease with dilutional hyponatremia. ${ }^{34}$

\section{Implication for therapy}

Conventional treatment of hyponatremia in HF patients is based largely on the restriction of fluid intake, saline and diuretic administration, but often these therapeutic approaches are ineffective. ${ }^{35,36}$ Hyponatremia in HF is frequently associated with reduced diuretic efficacy due to diminished distal tubular sodium delivery and secondary hyperaldosteronism. This could be particularly problematic when patients are not compliant with restrictions in free water intake. $^{37}$

A combination of hypertonic saline solution (HSS) and loop diuretics is often added to fluid restriction, but this more aggressive treatment is usually advocated for patients with severe hyponatremia who have profound neurological symptoms. ${ }^{38}$ Licata et al studied the effects of high-dose furosemide and small-volume HSS infusion (group 1) in comparison with a high dose of furosemide as bolus (group 2) in 107 patients with refractory CHF who were unresponsive to high oral doses of furosemide. ${ }^{39}$ A significant increase in daily diuresis and natriuresis was observed in both groups, but it was more significant in the group receiving HSS $(P<0.05)$. The serum sodium level increased in group 1 and decreased in group $2(P<0.05)$. HSS administration was well tolerated. It also improved the quality of life and potentiates the diuretic action of furosemide, overcoming established resistance to loop diuretics.

The $\mathrm{V}_{2}$ receptor antagonists may be viewed as the new class of agents for removing excess body water. These "aquaretic" agents have many favorable properties in comparison with loop diuretic..$^{9,11,39,40}$ One in particular is its property to improve serum sodium concentrations and increase plasma osmolality without depletion of potassium, changes in blood pressure, renal function or neurohormonal activation. In comparison with furosemide, tolvaptan increased urine output without a decrease in renal blood flow and glomerular filtration rate. ${ }^{40}$

Gheorghiade et al randomized tolvaptan alone versus fluid restriction plus placebo in 28 hospitalized patients with serum sodium concentration $<135 \mathrm{mEq} / \mathrm{L}$. Tolvaptan was started at $10 \mathrm{mg} /$ day and titrated to $60 \mathrm{mg}$ /day. Active treatment was continued for up to 27 days, with a follow-up until 65th day. Normalization of serum sodium (primary endpoint) occurred in $50 \%$ of patients by day 4 when treated with tolvaptan and by day 8 on fluid restriction $(P<0.03)$ with a significant greater increase of serum sodium concentration in the tolvaptan group compared to the fluid restriction group at their last inpatient visit. ${ }^{41}$

The Food and Drug Administration (FDA) has approved the use of tolvaptan for the treatment of clinically significant hypervolemic and euvolemic hyponatremia (serum sodium concentration $<125 \mathrm{mEq} / \mathrm{L}$ or less marked hyponatremia that is symptomatic and has resisted correction), including patients with HF, cirrhosis and SIADH. ${ }^{42}$

\section{Other vasopressin receptor antagonist}

Lixivaptan (VPA-985) is another oral $\mathrm{V}_{2}$-receptor selective antagonist. In a multicenter, randomized, placebo-controlled trial, ${ }^{43}$ lixivaptan appeared to be effective and safe in treatment of water retention and dilutional hyponatremia such as SIADH, HF and liver cirrhosis. Abraham et al investigated in a randomized, double-blind, placebo-controlled study the aquaretic response to increasing doses (10 to $400 \mathrm{mg}$ single dose) of lixivaptan in 42 diuretic-requiring patients with mild-to-moderate $\mathrm{CHF}^{44}$ This study demonstrated a dose-dependent increase in solute-free water excretion and improvement in serum sodium concentration after $\mathrm{V}_{2}$ receptor antagonist treatment. Higher doses of lixivaptan may produce significant dehydration and will require close monitoring with their use.

At present, no long-term outcome data are available. The ongoing BALANCE study, a multicenter, randomized, double-blind placebo controlled trial designed to test the effects of titrated dose of lixivaptan administered for 60 days, on short- and long-term outcomes in hyponatremic patients with advanced HF. The primary end point of the 
study is the efficacy and safety of lixivaptan in normalizing serum sodium levels and reducing congestion in HF patients with hyponatremia. Secondary end point includes all cause mortality, HF hospitalization, cardiovascular effects and weight loss. ${ }^{45}$

Conivaptan is the only intravenous combined $\mathrm{V}_{1 \mathrm{a}} / \mathrm{V}_{2}$ receptor antagonist that has been evaluated in humans and is FDA-approved for the treatment of euvolemic and hypervolemic hyponatremia. ${ }^{42}$ Experimental studies showed that conivaptan has a good pharmacological profile ${ }^{46}$ and is a potent inhibitor of AVP-induced protein synthesis of cardiomyocytes. It may have beneficial effects in the development and regression of cardiomyocyte hypertrophy. ${ }^{47}$ Combined $\mathrm{V}_{1 \mathrm{a}} / \mathrm{V}_{2}$ receptor antagonists might be useful in diseases associated with a combination of increased peripheral resistance and dilutional hyponatremia.

Human studies in patients with stable advanced chronic HF showed that conivaptan induces a dose-dependent increase in urine output, decrease of pulmonary capillary wedge pressure, right atrial pressure ${ }^{48}$ and improvement in serum sodium concentration. ${ }^{49}$ Current plans for conivaptan are focused on treatment for AHFS. Recently, Goldsmith et al performed a pilot study to evaluate the efficacy and safety of intravenous conivaptan in treating AHFS. ${ }^{50}$ The results of this study showed that conivaptan increases urine output significantly more than placebo. Conivaptan was well tolerated with no evidence of worsening HF. Further studies are still needed to determine the role of this drug in treatment of AHFS and hyponatremia.

\section{Tolvaptan in other hyponatremic settings}

Although the clinical manifestations are different for SIADH, liver cirrhosis, and HF, they share the same pathophysiologic mechanism responsible for persistent hyponatremia nonosmotically stimulated AVP release. The efficacy of tolvaptan in improving euvolemic and hypervolemic hyponatremia due to SIADH or liver cirrhosis was tested in two trials previously mentioned. Excluding hypothyroidism, adrenal insufficiency, advanced renal disease (creatinine $>3.5 \mathrm{mg} / \mathrm{dL}$ ), Child-Pugh score $>10$, serum sodium concentration $<120 \mathrm{mEq} / \mathrm{L}$ with neurologic impairment, and systolic hypotension, the SALT-1 and SALT-2 trials found that tolvaptan was effective in increasing serum sodium concentration at day 4 and day 30 also in these hyponatremic settings. The improvement in serum sodium concentration also significantly improved the scores for the Mental Component Summary (for vitality, social functioning, emotionally limited accomplishment, calmness, and sadness) of the SF 12 Health survey. ${ }^{28}$
Another potential clinical application of vasopressin receptor antagonists that is under investigation is its use in autosomal-dominant polycystic kidney disease (ADPKD). There are currently no good treatment options to retard progression of this condition and most patients require renal replacement therapy and/or renal transplantation. The morbidity and mortality associated with ADPKD is substantial. The vasopressin $\mathrm{V}_{2}$ receptors have been implicated in cyst formation and enlargement in polycystic kidney disease. The long-term safety and efficacy of tolvaptan in retarding (rate of renal volume change) progression of ADPKD is currently being studied. ${ }^{51}$

\section{Conclusion}

Hyponatremia in HF is not just a mere inconvenience. It is an independent predictor of adverse outcomes including longer hospital stay, higher readmission rates, and increased short- and long-term mortality. The use of tolvaptan has been shown to induce a rapid and sustained aquaretic response useful for treatment of hyponatremia in patients with acute and chronic HF. Tolvaptan improves short-term outcomes and is proven to be safe in the treatment of AHFS, especially in hyponatremic settings. Further prospective studies of the vaptans, using titrated doses based on serum sodium and clinical status, are necessary to determine whether serum sodium normalization will be translated into a better longterm prognosis in selected hyponatremic patients with HF.

\section{Disclosures}

The authors declare no conflicts of interest.

\section{References}

1. Lee DS, Austin PC, Rouleau JL, et al. Predicting mortality among patients hospitalized for heart failure: derivation and validation of a clinical model. JAMA. 2003;290:2581-2587.

2. Fall PJ. Hyponatremia and hypernatremia: a systematic approach to causes and their correction. Postgrad Med. 2000;107:75-82.

3. Gheorghiade M, Hellkamp AS, Pina IL, et al. Hemodynamic characterization and prognostic value of persistent hyponatremia in patients with severe heart failure in the ESCAPE trial. J Am Coll Cardiol. 2005;(Suppl):145A.

4. Janicic N, Verbalis JG. Evaluation and management of hypo-osmolality in hospitalized patients. Endocrinol Metab Clin North Am. 2003;32: 459-481.

5. Hawkins RC. Age and gender as risk factors for hyponatremia and hypernatremia. Clin Chim Act. 2003;337:169-172.

6. Sica DA. Sodium and water retention in heart failure and diuretic therapy: basic mechanisms. Cleve Clin J Med. 2006;73:S2-S7.

7. Goldsmith SR, Gheorghiade M. Vasopressin antagonism in heart failure. J Am Coll Cardiol. 2005;46(10):1785-1791.

8. Schrier RW, Berl T, Anderson RJ. Osmotic and nonosmotic control of vasopressin release. Am J Physiol. 1979;236(4):F321-F332.

9. Jard S. Mechanisms of action of vasopressin and vasopressin antagonists. Kidney Int Suppl. 1988;26:S38-S42. 
10. Verbalis JG. Vasopressin $\mathrm{V}_{2}$ receptor antagonists. J Mol Endocrinol. 2002;29:1-9.

11. Sica DA. Hyponatremia and heart failure - pathophysiology and implications. Congest Heart Fail. 2005;11:274-277.

12. Lee WH, Packer M. Prognostic importance of serum sodium concentration and its modification by converting-enzyme inhibition in patients with severe chronic heart failure. Circulation. 1986;73:257-267.

13. Rich MW, Beckham V, Wittenberg C, Leven CL, Freedland KE, Carney RM. A multidisciplinary intervention to prevent the readmission of elderly patients with congestive heart failure. $N$ Engl J Med. 1995;333:1190-1195.

14. Klein L, O'Connor CM, Leimberger JD, et al. Lower serum sodium is associated with increased short-term mortality in hospitalized patients with worsening heart failure: results from the Outcomes of a Prospective Trial of Intravenous Milrinone for Exacerbations of Chronic Heart Failure (OPTIME-CHF) study. Circulation. 2005;111:2454-2560.

15. Rusinaru D, Buiciuc O, Leborgne L, Slama M, Massy Z, Tribouilloy C. Relation of serum sodium level to long-term outcome after a first hospitalization for heart failure with preserved ejection fraction. Am J Cardiol. 2009;103:405-410.

16. Gheorghiade M, Abraham WT, Albert NM, et al; OPTIMIZE-HF Investigators and Coordinators. Relationship between admission serum sodium concentration and clinical outcomes in patients hospitalized for heart failure: an analysis from the OPTIMIZE-HF registry. Eur Heart $J$. 2007;28(8):980-988.

17. Gheorghiade M, Rossi JS, Cotts W, et al. Characterization and prognostic value of persistent hyponatremia in patients with severe heart failure in the ESCAPE trial. Arch Intern Med. 2007;167:1998-2005.

18. Ghali JK, Hamad B, Yasothan U, Kirkpatrick P. Tolvaptan. Nat Rev Drug Discov. 2009;8:611-612.

19. Shoaf SE, Bramer SL, Bricmont P, Zimmer CA. Pharmacokinetic and pharmacodynamic interaction between tolvaptan, an non-peptide AV antagonist and furosemide or hydrochlorothiazide. $J$ Cardiovasc Pharmacol. 2007;50:213-212.

20. Shoaf SE, Elizari MV, Wang Z, et al. Tolvaptan administration does not affect steady state amiodarone concentrations in patients with cardiac arrhythmias. J Cardiovasc Pharmacol Ther. 2005;10:165-171.

21. Kondo K, Ogawa H, Yamashita H, et al. 7-Chloro-5-hydroxy-1-[2-methyl4-(2-methylbenzoyl-amino)benzoyl]-2,3,4,5-tetrahydro-1H-1-benzazepine (OPC-41061): a potent, orally active non-peptide arginine vasopressin $\mathrm{V}_{2}$ receptor antagonist. Bio org Med Chem. 1999;7:1743-1754.

22. Hirano T, Yamamura Y, Nakamura S, Onogawa T, Mori T. Effects of the $\mathrm{V}_{2}$-receptor antagonist OPC-41061 and the loop diuretic furosemide alone and in combination in rats. J Pharmacol Exp Ther. 2000;292:288-294.

23. Ohnishi A, Orita Y, Takagi N, et al. Aquaretic effect of a potent, orally active, non peptide $\mathrm{V}_{2}$ antagonist in men. $J$ Pharmacol Exp Ther. 1995;272:546-551.

24. Gheorghiade M, Niazi I, Ouyang J, Czerwiec F, Kambayashi J, Orlandi C; Tolvaptan investigators. Vasopressin receptor blockade in patients with congestive heart failure: results from a randomized, double-blind study. Circulation. 2003;107:2690-2696.

25. Gheorghiade M, Gattis WA, O'Connor CM, et al; Acute and Chronic Therapeutic Impact of a Vasopressin Antagonist in Congestive Heart Failure (ACTIV in CHF) Investigators. Effects of tolvaptan, a vasopressin antagonist, in patients hospitalized with worsening heart failure: a randomized controlled trial. JAMA. 2004;291:1963-1971.

26. Rossi J, Bayram M, Udelson JE, et al. Improvement in hyponatremia during hospitalization for worsening heart failure is associated with improved outcomes: insights from the Acute and Chronic Therapeutic Impact of a Vasopressin Antagonist in Chronic Heart Failure (ACTIV in CHF) trial. Acute Card Care. 2007;9:82-86.

27. Filippatos G, Rossi J, Lloyd-Jones DM, et al. Prognostic value of blood urea nitrogen in patients hospitalized with worsening heart failure: insights from the Acute and Chronic Therapeutic Impact of a Vasopressin Antagonist in Chronic Heart Failure (ACTIV in CHF) study. $J$ Card Fail. 2007;13:360-364.
28. Schrier RW, Gross P, Gheorghiade M, et al. Tolvaptan, a selective oral vasopressin $\mathrm{V}_{2}$-receptor antagonist, for hyponatremia. $N$ Engl J Med. 2006;55:2099-2112.

29. Udelson JE, McGrew F, Flores E, et al. Multicenter randomized, double-blind, placebo-controlled study on the effect of oral tolvaptan on left ventricular dilation and function in patients with heart failure and systolic dysfunction. J Am Coll Cardiol. 2007;49:2151-2159.

30. Gheorghiade M, Orlandi C, Burnett JC, et al. Rationale and design of the multicenter, randomized, double-blind, placebo-controlled study to evaluate the Efficacy of Vasopressin antagonism in Heart Failure: Outcome Study with Tolvaptan (EVEREST). J Card Fail. 2005;11:260-269.

31. Gheorghiade M, Konstam MA, Burnett JC Jr, et al; Efficacy of Vasopressin Antagonism in Heart Failure Outcome Study With Tolvaptan (EVEREST) Investigators. Short-term clinical effects of tolvaptan, an oral vasopressin antagonist, in patients hospitalized for heart failure: the EVEREST Clinical Status Trials. JAMA. 2007;297:1332-1343.

32. Konstam MA, Gheorghiade M, Burnett JC Jr, et al; Efficacy of Vasopressin Antagonism in Heart Failure Outcome Study With Tolvaptan (EVEREST) Investigators. Effects of oral tolvaptan in patients hospitalized for worsening heart failure: the EVEREST Outcome Trial. JAMA. 2007;297:1319-1331.

33. Sterns RH, Nigwekar SU, Hix JK. The treatment of hyponatremia. Semin Nephrol. 2009;29:282-299.

34. Food and Drug Administration. FDA labeling information. FDA web site. http://www.accessdata.fda.gov/drugsatfda_docs/label/2009/ 022275lbl. Accessed Jan 28, 2009.

35. Ghali JK. Mechanisms, risks, and new treatment options for hyponatremia. Cardiology. 2008;111:147-157.

36. Goldsmith SR. Treatment options for hyponatremia in heart failure. Heart Fail Rev. 2009;14:65-73.

37. Brater DC. Diuretic Therapy. N Engl J Med. 1998;339:387-395.

38. Goh KP. Management of hyponatremia. Am Fam Physician. 2004;69:2387-2394.

39. Licata G, Di Pasquale P, Parrinello G, et al. Effects of high-dose furosemide and small-volume hypertonic saline solution infusion in comparison with a high dose of furosemide as bolus in refractory congestive heart failure: Long-term effects. Am Heart J. 2003;145:459-466.

40. Costello-Boerrigter LC, Smith WB, Boerrigter G, et al. Vasopressin2-receptor antagonism augments water excretion without changes in renal hemodynamic or sodium and potassium excretion in human heart failure. Am J Physiol Renal Physiol. 2006;290:F273-F278.

41. Gheorghiade M, Gottlieb SS, Udelson JE, et al; Tolvaptan Investigators. Vasopressin $\mathrm{V}(2)$ receptor blockade with tolvaptan versus fluid restriction in the treatment of hyponatremia. Am J Cardiol. 2006;97:1064-1067.

42. Food and Drug Administration. FDA labeling information. http://www. fda.gov/Drugs/default.htm. Accessed Jan 28, 2009.

43. Wong F, Blei AT, Blendis LM, Thuluvath PJ. A vasopressin receptor antagonist (VPA-985) improves serum sodium concentration in patients with hyponatremia: a multicenter, randomized, placebo controlled trial. Hepatology. 2003;37:182-191.

44. Abraham WT, Shamshirsaz AA, McFann K, Oren RM, Schrier RW. Aquaretic effect of lixivaptan, an oral, non-peptide, selective $\mathrm{V}_{2}$ receptor vasopressin antagonist, in New York Heart Association functional class II and III chronic heart failure patients. $J$ Am Coll Cardiol. 2006;47:1615-1621.

45. THE BALANCE Study: Treatment of Hyponatremia Based on Lixivaptan in NYHA Class III/IV Cardiac Patient Evaluation. http://www. clinicaltrials.gov. Accessed August 12, 2009.

46. Yatsu T, Tomura Y, Tahara A, et al. Pharmacological profile of YM087, a novel nonpeptide dual vasopressin $\mathrm{V}_{1 \mathrm{a}}$ and $\mathrm{V}_{2}$ receptor antagonist, in dogs. Eur J Pharmacol. 1997;321:225-230.

47. Tahara A, Tomura Y, Wada K, et al. Effect of YM087, a potent nonpeptide vasopressin antagonist, on vasopressin-induced protein synthesis in neonatal rat cardiomyocyte. Cardiovasc Res. 1998 $38: 198-205$. 
48. Udelson JE, Smith WB, Hendrix GH, et al. Acute hemodynamic effects of conivaptan, a dual $\mathrm{V}_{1 \mathrm{~A}}$ and $\mathrm{V}_{2}$ vasopressin receptor antagonist, in patients with advanced heart failure. Circulation. 2001;104: 2417-2423.

49. Ghali JK, Koren MJ, Taylor JR, et al; for the conivaptan study group. Efficacy and safety of oral conivaptan: $\mathrm{A} \mathrm{V}_{1 \mathrm{a}} / \mathrm{V}_{2}$ vasopressin receptor antagonist, in patients with advanced heart failure. J Clin Endocrinol Metab. 2006;91:2145-2152.
50. Goldsmith SR, Elkayam U, Haught WH, Barve A, He W. Efficacy and safety of the vasopressin $\mathrm{V}_{1 \mathrm{~A}} / \mathrm{V}_{2}$-receptor antagonist conivaptan in acute decompensated heart failure: a dose-ranging pilot study. J Card Fail. 2008; 14:641-647.

51. TEMPO 3/4 Trial Tolvaptan Efficacy and Safety in Management of Polycystic Kidney Disease and Its Outcomes (TEMPO3/4). http:/www. clinicaltrials.gov/ct2/show/NCT00428948?term_TEMPO\& rank_1. Accessed February 28, 2008.

\section{Publish your work in this journal}

The International Journal of Nephrology and Renovascular Disease is an international, peer-reviewed open-access journal focusing on the pathophysiology of the kidney and vascular supply. Epidemiology, screening, diagnosis, and treatment interventions are covered as well as basic science, biochemical and immunological studies. The journal welcomes original research, clinical studies, reviews \& evaluations, expert opinion and commentary, case reports and extended reports. The manuscript management system is completely online and includes a very quick and fair peerreview system, which is all easy to use. Visit http://www.dovepress.com/ testimonials.php to read real quotes from published authors.

Submit your manuscript here: http://www.dovepress.com/international-journal-of-nephrology-and-renovascular-disease-journal 